\title{
Pengaruh Pemberian Vitamin E dan Deksametason Terhadap Gambaran Histopatologi Jantung Tikus Putih Jantan
}

\author{
(THE EFFECT OF VITAMIN E AND DEXAMETASONE TO HISTOPATOLOGICAL OF \\ WHITE MALE RATS HEART)
}

\section{Ayu Prawitasari Citra Pratama ${ }^{1 *}$, I Ketut Berata ${ }^{2}$, Samsuri $^{3}$, I Made Merdana ${ }^{3}$}

${ }^{1}$ Praktisi Dokter Hewan di Banyuwangi Jawa Timur, ${ }^{2}$ Laboratorium Patologi Veteriner, Fakultas Kedokteran Hewan Universitas Udayana, Denpasar, Bali. ${ }^{3}$ Laboratorium Famakologi dan Farmasi Veteriner Fakultas Kedokteran Hewan Universitas Udayana’ Denpasar, Bali.

*Email: ayuprawitasaricitrapratama@gmail.com

\begin{abstract}
ABSTRAK
Deksametason merupakan glukokortikoid sintetik yang banyak digunakan dalam masyarakat. Penggunaan deksametason dosis besar dalam jangka waktu yang panjang dapat berpengaruh terhadap jantung. Vitamin E merupakan vitamin yang larut dalam lemak dan bertindak sebagai antioksidan yang mampu mengatasi radikal bebas dan stres oksidatif. Penelitian ini bertujuan untuk mengetahui efek pemberian vitamin E terhadap jantung tikus putih (Rattus norvegicus) akibat pemberian deksametason. Penelitian ini menggunakan 25 ekor tikus putih jantan berumur 2-3 bulan dengan berat 200-300 gram. Tikus dikelompokkan menjadi lima kelompok perlakuan dan lima ulangan. Tikus diadaptasikan selama satu minggu selanjutnya tikus diberikan perlakuan selama 14 hari. Pada kelompok perlakuan P0 sebagai kontrol negatif tidak diberikan perlakuan. Kelompok perlakuan P1, P2, P3 dan P4 diberikan deksametason secara injeksi subkutan dengan dosis $0,13 \mathrm{mg} / \mathrm{kg}$ BB. Vitamin E diberikan peroral sebagai berikut: P2 dosis $100 \mathrm{mg} / \mathrm{kg} \mathrm{BB}, \mathrm{P} 3$ dosis $150 \mathrm{mg} / \mathrm{kg} \mathrm{bb}$, dan P4 dosis 200 $\mathrm{mg} / \mathrm{kg}$ BB. Setelah 14 hari tikus dieutanasi, kemudian dinekropsi. Organ jantung diambil dan dimasukkan ke dalam neutral buffered formalin untuk fiksasi, selanjutnya dilakukan proses pembuatan preparat histopatologis dengan pewarnaan Hematoksilin Eosin. Parameter yang diamati adalah gambaran peradangan dan nekrosis pada jantung. Hasil pengamatan histopatologi menunjukkan pemberian vitamin E secara peroral dengan dosis $200 \mathrm{mg} / \mathrm{kg}$ bb berpengaruh sangat nyata terhadap perbaikan organ jantung tikus putih yang diberikan deksametason dosis $0,13 \mathrm{mg} / \mathrm{kg}$ BB. Simpulan dari penelitian ini adalah vitamin E dapat menghambat kerusakan jantung akibat efek samping deksametason.
\end{abstract}

Kata kunci: deksametason; jantung; tikus putih; vitamin E

\section{ABSTRACT}

Dexamethasone is a widely used synthetic glucocorticoid by people. However, the use of high doses of the long term can affect the heart. The heart is the place where drugs and other toxic substances are metabolized. However, specific studies in examining the effect of dexamethasone on heart's histopathology are rare. Vitamin E is a fat-soluble vitamin that acts as an antioxidant which can help the body to eliminate oxidative stress in cells. The aim of this study is to know the effect of vitamin E in rat's (Rattus norvegicus) heart given dexamethasone. This study used 25 male rats (Rattus norvegicus), which were two-three months old and 200$300 \mathrm{~g}$ of weight. Rats were grouped into five treatment groups and five repeats. Rats adapted for a week, and furthermore, rats were given treatments for 14 days. In the P0 treatment group rats given only food and drink (negative control). Treatment group P1, P2, P3, and P4 were given dexamethasone $0.13 \mathrm{mg} / \mathrm{kg}$ by subcutaneous injection. Vitamin E administrated orally with the following doses: P2 (100 mg/kg), P3 (150 mg/kg), and P4 (200 mg/kg). After 14 days, then the rats were necropsied to collect the heart. Next, the heart was put into Neutral Buffered Formalin (NBF) for fixation, then stained with hematoxylin-eosin staining (HE). The observed 
parameters were inflammation and necrosis of the heart. The result showed administration of $200 \mathrm{mg} / \mathrm{kg}$ of vitamin $\mathrm{E}$ had highly significant $(\mathrm{P}<0.01)$ to repair of rats' heart tissue which were given $0.13 \mathrm{mg} / \mathrm{kg}$ of dexamethasone via subcutaneous injection rather than $200 \mathrm{mg} / \mathrm{kg}$ of vitamin $\mathrm{E}$. The conclusions of this study are vitamin $\mathrm{E}$ can against heart damage due to side effects of dexamethasone.

Keywords: dexamethasone; heart; rats; vitamine E

\section{PENDAHULUAN}

Deksametason adalah salah satu golongan obat kortikosteroid yang masuk ke dalam kelompok glukokortioid sintetik (Indayani et al., 2015) Deksametason mulai dikenal pada tahun 1950 dengan rumus molekul $\mathrm{C}_{22} \mathrm{H}_{29} \mathrm{FO}_{5}$ (Iskandarsyah et al., 2003). Kortikosteroid merupakan hormon yang diproduksi oleh tubuh pada bagian korteks dari kelenjar adrenal. Deksametason mempunyai potensi anti inflamasi yang sangat kuat (Indranarum et al., 2003). Efek samping penggunaan deksametason pada organ jantung dapat menyebabkan terjadinya kerusakan seperti hiperemi, hemoragi dan nekrosis pada organ jantung (Aisyah et al., 2014).

Biasanya pada jantung ditemukan sel radang yang tersebar di miokardium juga dengan disertai perdarahan dan nekrosis (Purnamasari et al., 2015). Kerusakan sel tersebut dipicu oleh darah yang mengandung deksametason yang dipompa oleh jantung. Organ jantung merupakan organ muskuler berongga yang dapat berkontraksi secara ritmik dan berfungsi memompa darah dalam sistem sirkulasi. Fungsi jantung sebagai pemompa darah tersebut yang menjadikan jantung sangat rentan terkena efek samping obat deksametason ini. Dimana pada proses farmakokinetika akan terjadi proses absorbsi, yaitu obat akan berpindah menuju sirkulasi darah.

Antioksidan adalah unsur kimia atau biologi yang dapat menetralisasi potensi kerusakan yang disebabkan oleh radikal bebas. Beberapa antioksidan endogen (seperti enzim superoxide-dismutase dan katalase) dihasilkan oleh tubuh, selain itu tubuh juga memerlukan antioksidan lain dari luar tubuh (Iorio, 2007). Diperlukan pemberian antioksidan untuk mengurangi terjadinya efek samping. Pemberian antioksidan ini bertujuan untuk mencegah kerusakan sel-sel tubuh. Antioksidan yang tinggi dapat ditemukan pada vitamin E. Vitamin E merupakan substansi esensial untuk proses metabolisme normal dalam tubuh dan merupakan salah satu vitamin yang dapat larut dalam lemak dan berfungsi sebagai antioksidan (Brigelius - Fhole, 1999). Vitamin E mempunyai kemampuan memutus rantai reaksi peroksidasi atau menangkap radikal bebas dengan cara bereaksi secara langsung dengan berbagai radikal peroksi organik sehingga mencegah terjadinya reaksi berantai serta dapat menekan terjadinya kerusakan peroksidatif (Bebas et al., 2016). Vitamin E dapat melindungi lemak agar tidak teroksidasi (Yulfiperius et al., 2003). Sehingga dalam penelitian ini diteliti pemberian vitamin $\mathrm{E}$ untuk mengurangi terjadinya efek samping deksametason pada organ jantung.

\section{METODE PENELITIAN}

\section{Sampel Penelitian}

Sampel yang digunakan dalam penelitian ini adalah 25 ekor tikus putih (Rattus norvegicus) jantan berumur 2-3 bulan, dengan berat badan 200-300 gr yang didapatkan di kota Denpasar, Provinsi Bali.

\section{Prosedur Penelitian}

Tikus dibagi ke dalam lima kelompok yang terdiri dari: kelompok kontrol negatif (P0) yang hanya diberikan pakan dan minum saja. Kelompok kontrol positif (P1) yang diberikan deksametason secara injeksi subkutan dengan dosis $0,13 \mathrm{mg} / \mathrm{kg}$ berat badan. Kelompok (P2) yang diberikan deksametason secara injeksi subkutan dengan dosis $0,13 \mathrm{mg} / \mathrm{kg}$ berat badan dan 
vitamin E peroral dengan dosis $100 \mathrm{mg} / \mathrm{kg}$ berat badan. Kelompok (P3) yang diberikan deksametason secara injeksi subkutan dengan dosis $0,13 \mathrm{mg} / \mathrm{kg}$ berat badan dan vitamin $\mathrm{E}$ peroral dengan dosis $150 \mathrm{mg} / \mathrm{kg}$ berat badan. Kelompok (P4) yang diberikan deksametason secara injeksi subkutan dengan dosis $0,13 \mathrm{mg} / \mathrm{kg}$ berat badan dan vitamin E peroral dengan dosis $200 \mathrm{mg} / \mathrm{kg}$ berat badan. Perlakuan ini dilaksanakan selama dua minggu. Selanjutnya tikus dinekropsi dan organ jantung diambil untuk pembuatan preparat histopatologi jaringan otot jantung.

\section{Pembuatan Preparat}

Lima kelompok tikus yang telah diberi perlakuan selama dua minggu diambil organ jantungnya untuk selanjutnya dilakukan pembuatan preparat dengan menggunakan metode pewarnaan Hematoxylin-Eosin (HE). Sampel organ jantung yang diambil setelah dinekropsi kemudian dipotong dengan ukuran $1 \mathrm{x} 1 \mathrm{x}$ $1 \mathrm{~cm}$, kemudian direndam dengan larutan neutral bufer formalin (NBF). Kemudian sampel organ yang telah dipotong diperkecil lagi dengan irisan tipis untuk disimpan dalam tisue cassette dan difiksasi ke dalam larutan NBF. Setelah selesai fiksasi, kemudian dilakukan proses dehidrasi dan clearing dengan satu sesi larutan yang terdiri dari: alkohol $70 \%$, alkohol $80 \%$, alkohol $90 \%$, alkohol $96 \%$, alkohol absolut, toluene, dan parafin secara bertahap selama satu hari. Sampel organ diblocking dengan menggunakan embedding set yang dituangi parafin cair kemudian didinginkan. Blok yang sudah dingin disectioning menggunakan microtome dengan ketebalan \pm 4-5 mikron. Proses yang terakhir adalah pewarnaan dengan metode Harris Hematoxylin Eosin (HE) dan mounting media. Selanjutnya preparat histopatologi diamati di bawah mikroskop dan dicatat perubahan mikroskopik yang ditemukan.

Variabel yang diperiksa dalam penelitian ini adalah peradangan dan nekrosis pada otot jantung. Pemeriksaan mikroskopik dilakukan masing-masing pada lima lapang pandang mikroskopik dengan pembesaran 400x. Hasil pemeriksaan selanjutnya diberi skor yaitu nekrosis pada jantung: 0 jika tidak ada nekrosis jantung, 1 jika ada nekrosis jantung bersifat fokal atau ringan, 2 jika ada nekrosis jantung bersifat multifokal atau sedang, 3 jika ada nekrosis jantung bersifat difusa atau berat. Peradangan pada jantung: 0 jika tidak ada infiltrasi sel radang, 1 jika ada infiltrasi sel radang bersifat fokal atau ringan jika, 2 (ada infiltrasi sel radang bersifat multi fokal atau sedang), dan 3 ( ada infiltrasi sel radang bersifat difusa atau berat).

\section{Analisis Data}

Data hasil pengamatan histopatologi dikumpulkan dan dianalisis secara statistik nonparametrik menggunakan uji KruskalWallis. Jika ada perbedaan nyata $(\mathrm{P}<0,05)$ maka dilanjutkan dengan uji MannWhitney untuk mengetahui perbedaan pengaruh antar dosis vitamin $\mathrm{E}$ yang diberian.

\section{HASIL DAN PEMBAHASAN}

Hasil pengamatan histopatologi jantung tikus putih jantan (Rattus norvegicus) diperoleh dari pengamatan preparat dengan lima lapang pandang pada setiap kelompok perlakuan. Pemeriksaan dilakukan dengan pengamatan perbesaran 400X. Perubahan histopatologi diperiksa berdasarkan adanya nekrosis dan peradangan.

Hasil pengamatan histopatologi jantung tikus putih jantan (Rattus norvegicus) pada semua kelompok perlakuan tersaji pada Tabel 1. 
Tabel 1. Tabulasi hasil pemeriksaan histopatologi jantung tikus putih kategori nekrosis dan peradangan pada semua kelompok perlakuan.

\begin{tabular}{lccccccccccc}
\hline Kelompok & \multicolumn{4}{c}{ Skor Nekrosis } & \multicolumn{1}{c}{ Skor Peradangan } \\
\cline { 2 - 11 } & 0 & 1 & 2 & 3 & 4 & 0 & 1 & 2 & 3 & 4 \\
\hline Kontrol negatif (P0) & 5 & - & - & - & - & 5 & - & - & - & - \\
Kontrol positif (P1) & - & - & 5 & - & - & 1 & 3 & 1 & - & - \\
Vitamin E 100mg/kg (P2) & - & 2 & 3 & - & - & 2 & 3 & - & - & - \\
Vitamin E 150mg/kg (P3) & - & 3 & 2 & - & - & 3 & 2 & - & - & - \\
Vitamin E 200mg/kg (P4) & 3 & - & - & 2 & - & 4 & 1 & - & - & - \\
\hline
\end{tabular}

Perubahan histopatologi yang paling berat didapatkan pada pengamatan kelompok kontrol positif. Pemberian dalam dosis yang tinggi dapat menyebabkan keracunan obat dapat mengakibatkan kerusakan pada fungsi berbagai organ (Suhita, et al., 2013). Kelompok P4 merupakan kelompok yang secara pengamatan histopatologi memiliki gambaran yang paling baik. Pada Gambar 5 dapat diamati bahwa jaringan menunjukan gambaran yang mendekati jaringan jantung yang normal. Sebanyak dua sampel masuk ke dalam kategori nekrosis dengan skor 3 dan satu sampel masuk ke dalam kategori peradangan dengan skor 1 . Berdasarkan pengamatan histopatologi P4 yang diberikan deksametason secara injeksi subkutan dengan dosis $0,13 \mathrm{mg} / \mathrm{kg}$ berat badan dan vitamin $\mathrm{E}$ peroral dengan dosis $200 \mathrm{mg} / \mathrm{kg}$ berat badan.

Hasil uji Kruskal-Wallis menunjukkan bahwa perolehan nilai setiap perlakuan untuk nekrosis adalah 0,023. Nilai ini menunjukkan terdapat perbedaan nyata $(\mathrm{P}<0,05)$ antara kontrol negatif dengan kelompok perlakuan lain. Nilai setiap perlakuan untuk peradangan adalah 0,075, yang berarti tidak terdapat perbedaan nyata $(\mathrm{P}>0,05)$ antara kelompok kontrol negatif dengan kelompok perlakuan.

Hasil dari uji Mann-Whitney untuk kategori nekrosis jantung adalah antara kelompok kontrol negatif (P0) dengan kontrol positif $(\mathrm{P} 1), \mathrm{P} 2$ dan $\mathrm{P} 3$ terdapat perbedaan yang sangat nyata $(\mathrm{P}<0.01)$, sedangkan antara kontrol negatif (P0) dengan P4 tidak terdapat perbedaan nyata
$(\mathrm{P}>0,05)$. Kemudian antara kontrol positif (P1) dengan P2 dan P3 tidak terdapat perbedaan yang nyata $(\mathrm{P}>0,05)$. Sedangkan antara kontrol positif (P1) dengan P4 terdapat perbedaan yang nyata $(\mathrm{P}<0,01)$.

Hasil penelitian pada perlakuan kontrol positf P1 (diberi deksametason $0,13 \mathrm{mg}$ / $\mathrm{kg}$ ) menunjukkan hasil yang berbeda nyata $(\mathrm{P}<0,05)$ dibandingkan dengan kontrol negatif P0 (tanpa pemberian deksametason). Hal ini berarti jaringan otot jantung mengalami perubahan histopatologi akibat pemberian deksametason. Hasil pemeriksaan histopatologi masing-masing kelompok perlakuan disajikan pada Gambar 1 sampai Gambar 5.

Dosis $200 \mathrm{mg} / \mathrm{kg}$ BB merupakan dosis vitamin $\mathrm{E}$ yang dapat meredam oksidasi akibat pemberian obat deksametason. Nekrosis pada jantung tikus putih ini disebabkan oleh pemberian deksametason. Perubahan gambaran sel jantung tersebut disebabkan karena peningkatan kadar glukosa darah sehingga merangsang pelepasan insulin dan menghambat masuknya glukosa ke dalam sel otot, selain itu dapat juga merangsang lipase yang sensitif dan menyebabkan lipolisis sehingga hasil akhirnya adalah peningkatan deposit lemak, lipogenesis, peningkatan pelepasan asam lemak, dan gliserol ke dalam darah (Suherman et al., 2009). Peningkatan asam lemak yang dimobilisasi dari jaringan adiposa dapat dipicu oleh glukokortikoid akan menstimulasi konversi asam amino menjadi glukosa (Burhanuddin et al., 20014). 


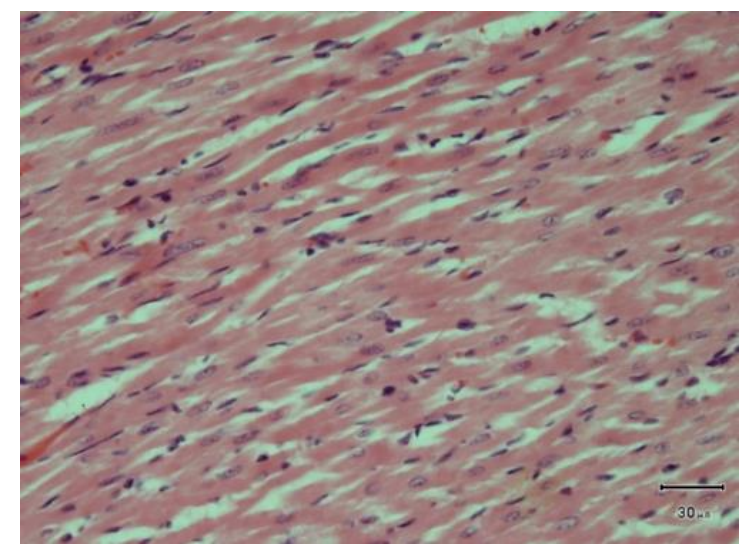

Gambar 1. Histopatologi jantung tikus putih kelompok kontrol negatif (400X, HE) tidak ditemukan adanya perubahan.

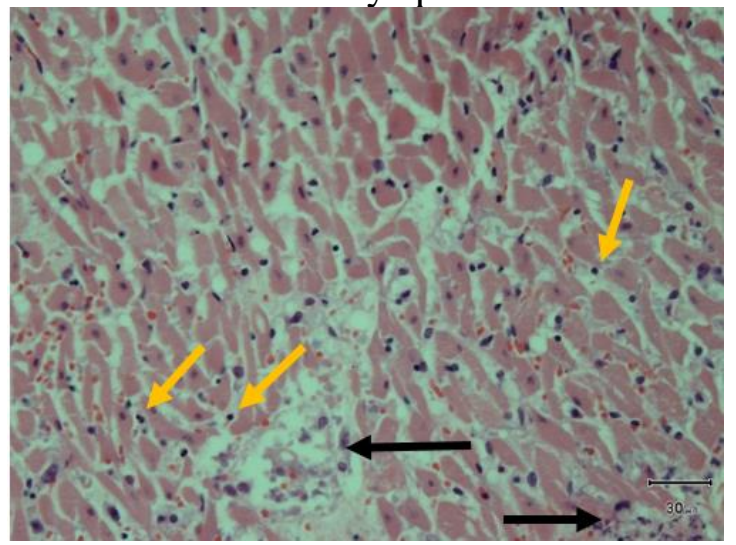

Gambar 2. Histopatologi jantung tikus putih kelompok kontrol positif (400x, HE) ditemukan adanya nekrosis multifokal (tanda panah kuning) dan peradangan yang bersifat fokal (tanda panah hitam).

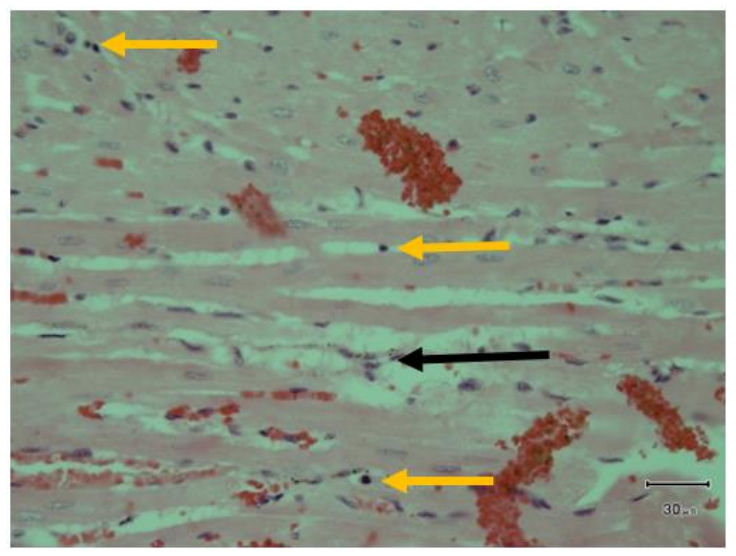

Gambar 3. Histopatologi jantung tikus putih kelompok P1 (400x, HE), ditemukan nekrosis multifokal (tanda panah kuning) dan peradangan bersifat fokal (tanda panah hitam).

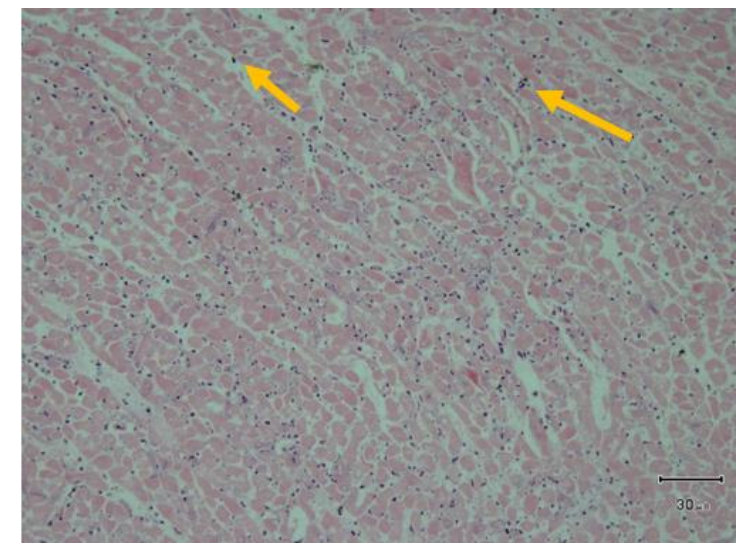

Gambar 4. Histopatologi jantung tikus putih kelompok P3 (200x, HE), ditemukan nekrosis yang bersifat fokal (tanda panah kuning).

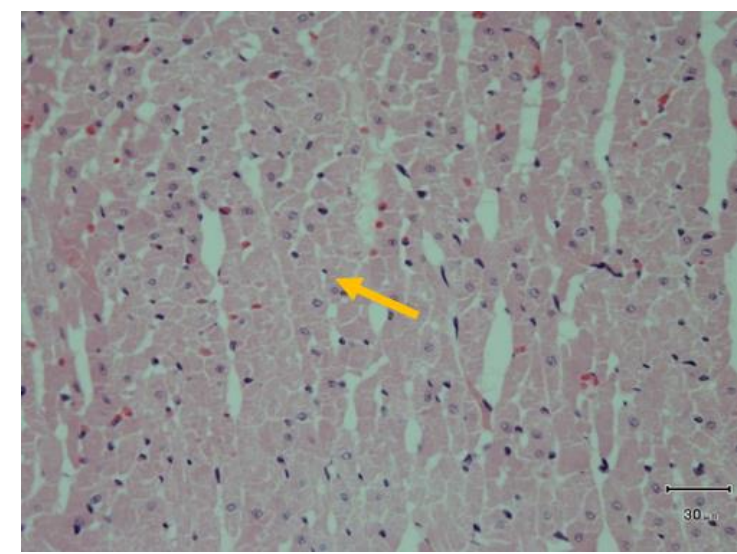

Gambar 5. Histopatologi jantung tikus putih kelompok P4 (400x, HE) ditemukan nekrosis yang bersifat fokal (tanda panah kuning).

Lipogenesis yang berlebihan menyebabkan sintesis apoprotein terhambat sehingga terjadi disagregasi ribosom dan penurunan sintesis protein yang berakibat pada kegagalan produksi ATP. Sel tanpa ATP menyebabkan sel tidak mampu melaksanakan fungsi vitalnya yang mengakibatkan kegagalan pompa membran sel, sehingga $\mathrm{Na}^{+}$dan air intraseluler bertambah dan kadar $\mathrm{K}^{+}$berkurang. Hal ini meyebabkan denaturasi protein sel dan penurunan $\mathrm{pH}$ intrasel, sehingga keadaan asam ini menyebabkan kromatin terlipat atau menggumpal yang merupakan salah satu perubahan inti tipikal yang disebut piknosis (Satiavani, 2010). 
Piknosis merupakan tahap awal kematian sel/jaringan. Inti sel mengecil dan nampak lebih bundar dengan warna lebih jelas (hiperkromatik). Inti sel tidak tampak memiliki anak inti (nukleolus), butir-butir kromatin, dan struktur inti lainnya (Berata et al., 2011). Kemungkinan peradangan yang terjadi merupakan reaksi infeksi pada suatu jaringan. Dimana reaksi peradangan suatu individu umumnya terjadi segera setelah infeksi atau cedera jaringan (Berata et al., 2011).

Pemberian vitamin E secara oral selama 2 minggu pada tikus putih yang diberi deksametason terbukti mengalami perbaikan namun secara statistik tidak signifikan pada semua perlakuan, yaitu P2 dengan dosis vitamin E $100 \mathrm{mg} / \mathrm{kg}, \mathrm{P} 3$ dengan dosis vitamin E $150 \mathrm{mg} / \mathrm{kg}$, sedangkan pada $\mathrm{P} 4$ dengan dosis vitamin $\mathrm{E}$ $200 \mathrm{mg} / \mathrm{kg}$ sudah ada perbaikan yang signifikan. Perbaikan yang terjadi dari nekrosis yang bersifat multifokal menjadi nekrosis bersifat fokal. Selain itu, Vitamin $\mathrm{E}$ juga dapat melindungi kerusakan membran biologis akibat radikal bebas. Vitamin E melindungi asam lemak tak jenuh pada membran fosfolipid, melindungi membran sel darah merah yang kaya akan asam lemak tak jenuh dari kerusakan akibat oksidasi. Selain itu, vitamin $\mathrm{E}$ juga melindungi lipoprotein dari sirkulasi LDL (low-density lipoprotein) teroksidasi (Dewoto, 2009).

Pada penelitian ini didapatkan hasil suplementasi vitamin E per oral terhadap jantung tikus putih yang diberi deksametason $0,13 \mathrm{mg} / \mathrm{kg}$ secara subkutan mengalami perbaikan, khususnya pada dosis $200 \mathrm{mg} / \mathrm{kg}$, dimana dari nekrosis bersifat multifokal menjadi nekrosis yang bersifat fokal. Namun pada dosis vitamin $\mathrm{E}$ $150 \mathrm{mg} / \mathrm{kg}$ nekrosis pada jantung belum mengalami perbaikan, mungkin dikarenakan kandungan antioksidan vitamin $\mathrm{E}$ yang diberikan belum mampu menangkal radikal bebas yang dihasilkan deksametason tersebut. Untuk dosis vitamin E $200 \mathrm{mg} / \mathrm{kg}$ sudah terdapat tiga jantung yang tidak mengalami nekrosis dan dua jantung mengalami nekrosis, sehingga secara statistik tidak signifikan dengan kontrol negatif. Hal ini bisa terjadi karena antioksidan dosis tinggi dapat menghentikan reaksi berantai radikal bebas dan mencegah kerusakan sel-sel normal (Aminullah et al., 2012).

\section{SIMPULAN DAN SARAN}

\section{Simpulan}

Pemberian deksametason dengan dosis $0,13 \mathrm{mg} / \mathrm{kg}$ dapat menyebabkan nekrosis (piknosis) bersifat multifokal. Pemberian vitamin E sampai dosis $200 \mathrm{mg} / \mathrm{kg}$ dapat memperbaiki lesi nekrosis.

\section{Saran}

Berdasarkan adanya peranan suplementasi vitamin $\mathrm{E}$ terhadap pengurangan efek samping pemberian deksametason pada tikus putih, maka dapat disarankan untuk dilakukan penelitian lebih lanjut tentang interaksi antara deksametason dengan vitamin $\mathrm{E}$ dalam jaringan otot jantung.

\section{UCAPAN TERIMA KASIH}

Ucapan terima kasih kepada staff Balai Besar Veteriner Denpasar, Laboratorium Patologi Veteriner, dan Laboratorium Farmakologi dan Farmasi Veteriner Fakultas Kedokteran Hewan Universitas Udayana yang telah membantu selama penelitian ini berlangsung.

\section{DAFTAR PUSTAKA}

Aisyah S, Balqis U, Friyan KE. 2015. Histopatologi Jantung Tikus Putih (Rattus norvegicus) Akibat Pemberian Minyak Jelantah. J. Medika Vet. 9(1): 27-28.

Aminullah Y, Wiranto, Susilaningsih N. 2012. Pengaruh Kombinasi Vitamin $C$ dan E terhadap Sistem Hemopoetik Penderita Kanker Kepala dan Leher yang Mendappat Kemoterapi Cipslatin. Med. Hosp. 1(2): 90.

Bridgelius-Flohe R, Traber MG. 1999. Vitamin E: Function and Metabolism. FASEB J. 13. 
Berata IK, Winaya IBO, Adi AAAM, Adnyana, IBW. 2011. Patologi Veteriner Umum. Denpasar: Swasta Nulus.

Bebas W, Buyona GL, Budiasa MK. 2016. Penambahan Vitamin E Pada Pengencer BTS ${ }^{\circledR}$ Terhadap Daya Hidup dan Motilitas Spermatozoa Babi Landrace Pada Penyimpanan $15^{\circ} \mathrm{C}$. Bul. Vet. Udayana. 8(1): 1-7.

Burhanuddin, Marianti A, Manggau, Faisal A. 2014. Pengaruh Pemberian Kombinasi Ekstrak Daun Kelor (Morinaga oleifera) dan Herba Sambiloto (Andrographis paniculata) Terhadap Penurunan Kadar Glukosa Darah Mencit Jantan (Mus Musculus) Akibat Efek Deksametason. JST Kesehatan. 4(1): 17-24.

Dewoto HR. 2009. Farmakologi Jdan Terapi Edisi 5. Jakarta: Fakultas Kedokteran Universitas Indonesia.

Indayani SI, Susilowati SRL. Pengaruh Pemberian Deksametason Terhadap Kerusakan Hepar Tikus Jantan (Ratus norvegicus) Galur Wistar. J. Online UM Ilmu Hayati 1(1): 1-7.

Indranarum T, Marowardoyo S. 2003. Kadar Plasma Kortisol pada Beberapa Macam Manifestasi Efek Samping Kortikosteroid pada Kulit. J. Berkala Ilmu Penyakit Kulit dan Kelamin. 15. Iorio EL. 2007. The Measurement of Oxidative Stress. International Observatory of Oxidative Stress, Free
Radicals and Antioxidant Systems. Special supplement to Bulletin. 4(1).

Iskandarsyah FA, Sudjaswadi R. 2003. Peningkatan Kelarutan Deksametason Melalui Pembentukan Dispersi Padat Dengan Hidroksipropil Metilselulosa. J. Farmasi Indonesia. 1(4): 152-160.

Purnamasari IAA, Berata IK, Kardena IM. 2015. Studi Histopatologi Organ Usus dan Jantung Anjing Terinfeksi Virus Parvo. Bul. Vet. Udayana. 7(2): 99-104. Satiavani I. 2010. Artikel karya ilmiah: Pengaruh Pemberian Deksametason Dosis Bertingkat Per Oral 30 Hari Terhadap Kerusakan Sel Hepar Tikus Wistar. Fakultas Kedokteran. Universitas Diponegoro.

Suherman, SK, Ascobat P. 2009. Adrenokortikotropin,

Adrenokortikosteroid, Analog-Sintetik dan Antagonisnya. Dalam: Farmakologi dan Terapi Edisi 5, Departemen Farmakologi dan Terapeutik Fakultas Kedokteran Universitas Indonesia, Jakarta. Pp. 496516.

Suhita NLPR, Sudira IW, Winaya IBO. 2013. Histopatologi Ginjal Tikus Putih Akibat Pemberian Ekstrak Pegagan (Centella asiatica) Peroral. Bul. Vet. Udayana. 5(2): 71-78.

Yulfiperius, Mokoginta I, Jusadi D. 2003. Pengaruh Kadar Vitamin E Dalam Pakan Terhadap Kualitas Telur Ikan Patin (Pangasius hypophythalmus). J. Iktiologi Indonesia. 3(1):11-18. 